\title{
Issues on the anthropocentric production systems
}

\author{
I. Kovács
}

Section of Sociology, Dep. Social Sciences, ISEG-UTL, Faculty of Economics and Management-Technical University of Lisbon

Rua Miguel Lupi, 20, P-1200 Lisboa, Portugal, tel. 3912537, fax. 3951885 e-mail: cs0015@keynes.iseg.utl.pt

\section{A. Brandão Moniz}

Industrial Sociology Group, FCT-UNL, Faculty of Sciences and Technology, Universidade Nova Lisboa Quinta da Torre, P-2825 Monte da Caparica, Portugal, tel. 3500225, fax.2954461, e-mail:abm@uninova.pt

\begin{abstract}
This paper analises the problems and trends of the introduction of anthropocentric production systems (APS), specifically in small less industrialised member states of the European Union. The aim of this paper is to characterize APS and to present some special considerations related to the socioeconomic factors affecting the prospects and conditions for APS that is defined as a system based on the utilization of skilled human resources and flexible technology adapted to the needs of flexible and participative organisation. Among socioeconomic factors, some critical aspects for the development of APS will be focused, namely technological infrastructure, management strategies, perceived impact of introduction of automated systems on the division of labour and organisational structure, educational and vocational training and social actors strategies towards industrial automation. This analysis is based on a sample of industrial firms, built up for qualitative analysis, and on case studies analysis that can be reference examples for further development of APS, and not just for economic policy purposes alone.

We have also analysed the type of existing industrial relations, the union and employer strategies and some aspects of public policies towards the introduction of new technologies in the order to understand the extente to which there exists obstacles to and favorable conditions for the diffusion of anthropocentric systems. Finally some recomendations are presented to stress the trends for the implementation and development of anthropocentric production systems.
\end{abstract}

\section{Keywords}

Anthropocentric production systems, labour skills and qualifications, organisation, vocational training, automation, industrial relations.

\section{SOME OF THE KEY CHARACTERISTICS OF APS}

Many terms are employed to illustrate the central features of new production systems: one-of-akind production, skill-based systems, flexible specialisation, customised quality-competitive production, human centred system and anthropocentric production system (APS). 
Although, the use of the APS designation is recent, a lot of their principles and ideas may be considered both as a development and integration of models recommended by social science specialists since the fifties and practised by innovative firms since the seventies.

APS can be defined as a production system which improves skills, participation in the decision-making processes and the quality of working life. In this system new technologies are moulded to valorise specific human capacities and to meet the needs of organisational structures designed to increase the participation of people in decision-making and the control of production processes, thus leading to a better quality of working life. However, there is no universally accepted definition. For this reason we decided to mention some of the APS definitions.

APS as a coherent set of technological and organisational innovations to improve productivity, quality and flexibility: "The production system that fits this condition is a computer-aided production system strongly based on skilled work and human decision-making combined with leading-edge technology. It can be called 'an anthropocentric production system." (Lehner, 1992: VII). The essential components of these systems are:

- flexible automation, supporting human work and decision-making

- a decentralised organisation of work, with flat hierarchies and a strong delegation of power and responsibilities, especially at shop-floor level;

- reduced division of labour;

- continuous, product-oriented up-skilling of people at work;

- product-oriented integration within the broader production processes.

Within this approach the combination of advanced technology and skilled work in a decentralised, product-oriented organisation leads to an intelligent manufacturing system able to support high quality and technological sophistication, rapid adjustment to change as well as diversification and the efficient use of resources (Lehner, 1992: IX).

According to another approach, APS represents a step in the evolutionary process of the production systems. In this sense, a new paradigm of production systems is emerging (Piore and Sabel) which will gradually displace the old mass production system in sectors whose activity involves advanced technology. The Fordist-Tayloristic approach is becoming increasingly inadequate in view of present economic, social and cultural conditions. The ability to adapt the products to costumer requirements by increasing variety, quality and short delivery times, are becoming the most important competitive factors. APS is seen as a competitive tool for the modernisation of European industry. For supporters of APS, Europe with its tradition for small batch production is in a comparatively more favourable position to improve APS than the USA, with its highly Tayloristic-Fordistic traditions (Brödner).

In this paper we consider APS to be synonymous with the concept of a human centred production system. APS is an alternative response but it is not "the one best way" to respond to the requirements of changing market conditions calling for flexibility, innovation, diversification, short delivery times and customisation. It is, however an adequate response to the new expectations and attitudes of people towards work.

At present there are many solutions - both technical and organisational - for improving firms' competitiveness. This is a new trend, insofar as, for some time there would appear to have been a strong tendency for production systems to converge in most of the economic activities of industrialised or industrialising countries. The Taylorist-Fordist principles were felt to be universally applicable. However, we disagree with this approach which considers APS to be new universal model displacing the old Taylorist-Fordist model. From our standpoint APS is an alternative strategy and a question of choice rather than "the one best way" of ensuring the best performance.

The technology-centred strategy is another choice for the improvement of highly automated production systems. There are underlying ideas, namely that economic superiority is based on technological sophistication in which competitiveness pressuposes hierarchical and centralised organisation. Technology is regarded as a mean of replacing people reduced to machine components in the automated system whose role is becoming more and more reduced through 
higher automation, leading to increased replacement of human skills. There are many other possible strategies arising from different combination of the principles of two basic strategies we know as human-centred and technology-centred strategies.

Table 1 Comparison of the technology-centred and human-centred approach

\begin{tabular}{|c|c|}
\hline Technology-centred Approach & Human-centred Approach \\
\hline $\begin{array}{l}\text { Introduction of new technologies with a view } \\
\text { to reducing human roles on the shop floor, } \\
\text { and labour costs }\end{array}$ & $\begin{array}{l}\text { Introduction of new technologies as a } \\
\text { complement to specific human capacities, } \\
\text { aimed at increasing funcional flexibility, } \\
\text { quality of products and of working life }\end{array}$ \\
\hline $\begin{array}{l}\text { Replacement of skills by technology, leading } \\
\text { to an increase in the de-skilling and de- } \\
\text { motivation of shop floor employees. }\end{array}$ & $\begin{array}{l}\text { Improvement of the quality and stability of } \\
\text { human resources at all levels for the improved } \\
\text { exploration of the potentials offered by new } \\
\text { technologies }\end{array}$ \\
\hline Centralised technical solutions & Decentralised technical solutions \\
\hline $\begin{array}{l}\text { Rigid work practices based on principles such } \\
\text { a centralisation, vertical and horizontal } \\
\text { separation of tasks and competence } \\
\text { specialisation }\end{array}$ & $\begin{array}{l}\text { Flexible work practices based on principles } \\
\text { such as decentralisation, multi-valence, } \\
\text { vertical and horizontal integration of tasks, } \\
\text { participation and co-operation }\end{array}$ \\
\hline Rigid hierarchic and professional boundaries & Supple boundaries \\
\hline $\begin{array}{l}\text { Passive role at operational level: execution of } \\
\text { simple tasks }\end{array}$ & $\begin{array}{l}\text { New professionalism at operational level: } \\
\text { autonomy to perform different, complex } \\
\text { tasks, capacity for problem solving, creativity } \\
\text { and autonomy, at individual or group level }\end{array}$ \\
\hline $\begin{array}{l}\text { Integration of units of firms by way of } \\
\text { computer assisted centralisation of } \\
\text { information, decisions and control }\end{array}$ & $\begin{array}{l}\text { Integration of parts of firms by way of } \\
\text { training, socialisation, communication- } \\
\text { cooperation and information accessibility, } \\
\text { participation in decision making and self- } \\
\text { control }\end{array}$ \\
\hline
\end{tabular}

The human-centred approach is directed towards the development of a flexible and decentralised production system. Here the potentials of technology complement human skills and specific human abilities are valorised.

In other words technology should not replace people, but rather improves their competence and decision making capacity. Flexibility is achieved using intuition, imagination, individual and collective know-how, existing skills and working methods enriched through new knowledge and methods.

These specific human abilities related to the management of the unexpected, are based on information which cannot be formalised and on an understanding of complex and nonstructured situations. The job is designed according to socio-technical principles: the improvement of variety, identity, sense of fulfilment and autonomy at work. Their aims are:

- the use of skills and abilities including tacit knowledge,

- the creation of favourable conditions for development and learning,

- the improvement of collaborative work.

These principles involve the integration of conception and execution, intellectual and manual functions through work enrichment with discretion in selection of work methods (in low automated work areas) or by the integration of planning, programming, processing and maintenance tasks (in highly automated areas). 
The work is structured in work groups with a high level of autonomy and self-control. The work group activity focuses on the main type of product, or on a small group of related products. The group tasks include planning and allocation of work: loading, setting, unloading the machines; programming, maintenance, quality and performance control. Various skills are required and job rotation among group members is used. At factory level the basic principles are:

- de-centralisation of the company, to form autonomous production units,

- collaborative relationship between departments,

- strong communication links between the groups, including informal and personal communication,

- co-operative relationship between specialists (engineers, technician) and operators (workers).

The technological dimension is developed by taking account of a desired decentralised organisational structure, requirements linked to team work, people's needs and motivations rather than ergonomic criteria alone. Technology should make the best use of human beings by developping tools to support skills and competence, should allow group work by grouping machines and software to support planning, control and scheduling activities as a group responsibility, and should support group autonomy by decentralised information, communication and transport systems.

The anthropocentric approach may be exemplified by ESPRIT-CIM projects 1199 (Human Centred CIM) and 534 (Development of a Flexible Automated Assembly Cell and Associated Human Factor Study), 6896 (CONSENS-Concurrent/Simultaneous Engineering System) and 8162 (QUALIT-Quality Assessment of Living with Information Technology) and ESPRIT 2338 (Integrated Manufacturing Planning and Control System, oriented to develop a decentralised system architecture with emphasis on shop-floor scheduling). These projects have been multi-disciplinary projects covering the technical, psychological and organisational aspects, with the co-operation between engineers and specialists from different social sciences. They recognise that "the joint optimisation of human and technical criteria is a pre-requisite to the development and successful implementation of technology" (Kidd, 1988, 297-302). Their aim is to improve economic results, as well as the quality of working life.

The development of an anthropocentric productive system, in accordance with humancentred principles, may be undertaken by implementing all principles in a complete system, using all the abovementioned elements, or by the introduction of some changes. The first case involves the shaping of new plants, whilst the second case requires modifications in accordance with APS principles. Such alterations may consist of the formation of working groups and/or "production islands", task re-organisation for their enrichment and de-centralisation methods.

Models and methods are necessary to analyse and design integrated socio-technical systems and evaluate the relationship between people-organisation-technology, based on interdisciplinary work and co-operation among technologists and social scientists. This interdisciplinary approach enables one to take into consideration the organisational structure chosen, users' needs and motivations in the development of production systems (Kidd, 1992 37).

\section{ADVANTAGES OF APS}

In a humanistic approach the promotion of APS is always desirable. However, we may well ask: is APS at present feasible in the context of the competitive imperatives of economic life?

The experiences reported in many studies show that the APS is not only a desirable model from a humanistic perspective, but can also lead to increased productivity, improved quality and greater effectiveness.

Market conditions have become unstable, very differentiated and extremely dynamic. Advanced technologies offer new opportunities, such as higher technical flexibility, a greater 
degree of quality and precision and the integration of different areas of activity. At the same time, people with a higher level of education and professional training expect jobs with enriched content besides participation possibilities in the decision-making processes. In this context the APS provides psychological, social and economic benefits. There are many case studies elaborated within the FAST Framework Programme that demonstrate the advantages of APS (LEHNER, 1992, 47). For example one German experience shows the following results:

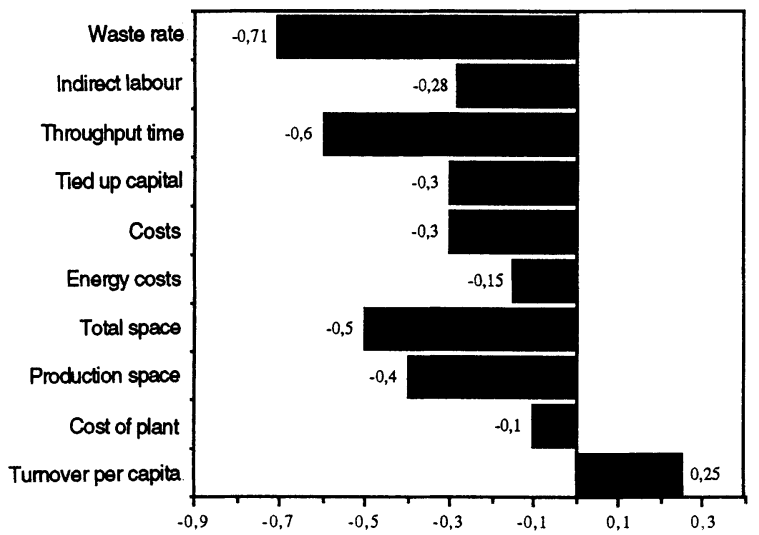

Figure 1 Performance and anthropocentric production systems (Kidd, 1992, 47).

Some examples of Flexible Manufacturing Systems show the economic advantages of the application of APS principles:

Table 2

\begin{tabular}{|l|c|c|c|c|c|}
\hline $\begin{array}{c}\text { Reduction } \\
\text { in } \%\end{array}$ & $\begin{array}{c}\text { Freudenberg } \\
\text { (D) } \\
\text { case No. 6 }\end{array}$ & $\begin{array}{c}\text { Sealectro } \\
\text { (GB) } \\
\text { case No. 11 }\end{array}$ & $\begin{array}{c}\text { Felten \& G. } \\
\text { (D) } \\
\text { case No. 19 }\end{array}$ & $\begin{array}{c}\text { Volvo } \\
(\mathrm{S}) \\
\text { case No. 23 }\end{array}$ & $\begin{array}{c}\text { Lukas } \\
(\mathrm{GB}) \\
\text { case No. 26 }\end{array}$ \\
\hline lead times & 80 & 50 & 50 & 80 & 55 \\
\hline stock & 15 & 45 & 50 & 50 & 50 \\
\hline $\begin{array}{l}\text { production } \\
\text { costs }\end{array}$ & $\begin{array}{c}\text { no data } \\
\text { available }\end{array}$ & 75 & 10 & 25 & $\begin{array}{c}\text { no data } \\
\text { available }\end{array}$ \\
\hline
\end{tabular}

Source: Brandt, 1991, 40.

Among the technical and economic benefits one may consider the following:
a) improved quality (less rejects and flaws)
b) increased responsiveness,
c) shorter throughput times,
d) lower indirect costs,
e) easier planning and control of production processes, 
f) simplified material flows,

g) smaller production areas

h) swifter response to quantitative and qualitative changes in demand,

i) less breakdowns,

j) increased capacity for innovation and continuos improvement.

Among the social-human benefits one may consider:

a) the increasing quality of working life,

b) higher job satisfaction through meaningful rewarding tasks,

c) higher degree of motivation and involvement,

d) greater personal flexibility and adaptation,

e) improved ability, creativity and skills of shop floor personnel,

f) enriched direct interpersonal communication and social relations,

g) increased collective and co-operative spirit,

h) greater capacity for collective learning of new practices.

We can thus conclude that within a flexible economy, APS may be regarded as a strategic answer to new economic requirements. Today, competitive advantages are gained from factors related to quality, flexibility, creativity and innovation.

The excellent results obtained by Japanese firms stem from organisational and human resource related factors *. According to Jaikumar's comparative study on FMS in the US and Japan metal sector, Japanese firms make better use of information-intensive technology than the US. firms. "With few exceptions, the flexible manufacturing systems installed in the US show an astonishing lack of flexibility. In many cases, they perform worse than the conventional technology they replace. The technology itself is not to blame; it is management that makes the difference. Compared with Japanese systems, those in US plants produce an order-ofmagnitude less variety of parts" (Jaikumar, 1986, 69). The US firms use FMS for the highvolume production of a few parts, whereas the Japanese firms use it for high-variety production of many parts at lower per unit costs.

Table 3 Comparison of Japanese FMS studies in US. and Japan

\begin{tabular}{|l|c|c|}
\hline \multicolumn{1}{|c|}{ Results } & US. & Japan \\
\hline System development time (years) & 2,5 to 3 & 1,25 to 1,75 \\
\hline Number of machines per system & 7 & 6 \\
\hline Types of parts produced per system & 10 & 93 \\
\hline Annual volume per part & 1727 & 258 \\
\hline Number of parts produced per day & 88 & 120 \\
\hline $\begin{array}{l}\text { Number of new parts introduced per } \\
\text { year }\end{array}$ & 1 & 22 \\
\hline Utilisation rate (two shifts) & $52 \%$ & $84 \%$ \\
\hline $\begin{array}{l}\text { Average metal-cutting time per day } \\
\text { (hours) }\end{array}$ & 8.3 & 20.2 \\
\hline
\end{tabular}

Source: Jaikumar, 1986, 70 .

\footnotetext{
* Altough the productive systems developed in Japan are in some key areas similar to anthropocentric system, as we shall mention later, in view of their specific features, they are regarded as "lean production".
} 
The performance disparity was mainly due to differences concerning the workforce's level of skill and type of work organisation. In US firms, management mastered the production system on the principles of scientific management. Here skilled blue-collar machinists were replaced by trained operators whose tasks were specified by management. The operators did not have the discretion to change procedures. In Japanese firms, highly skilled people with multi-functional responsibilities work in small teams. Operators on the shop floor can introduce programming changes and are responsible for writing new programs.

In the "lean production" model the emphasis is on the relations between the firm and suppliers and customers. In the APS model the emphasis is above all on internal competence and the achievement of functional flexibility, qualified versatile people. In the "lean production" model, technology is accepted piecemeal whereas, in the APS model, technology is specifically adapted to peoples and organisational needs. The so-called Japanese "lean production" model is in some aspects similar to that of APS, differences do though exist:

Table 4 Comparison of APS and "lean production"

\begin{tabular}{|l|l|l|}
\hline \multicolumn{1}{|c|}{ Characteristics } & \multicolumn{1}{c|}{ Lean Production } & \multicolumn{1}{c|}{ APS } \\
\hline Aims & $\begin{array}{l}\text { Increasing productivity, } \\
\text { industrial modernisation, } \\
\text { based on human resources } \\
\text { and organisation }\end{array}$ & Same \\
\hline Qualifications & Training & Education/training \\
\hline Technology & $\begin{array}{l}\text { No need for a specific } \\
\text { technology }\end{array}$ & $\begin{array}{l}\text { Technology should be } \\
\text { specifically adapted }\end{array}$ \\
\hline $\begin{array}{l}\text { Organisational } \\
\text { principles }\end{array}$ & $\begin{array}{l}\text { Organisation of business, } \\
\text { plant and shop floor }\end{array}$ & $\begin{array}{l}\text { Organisation of plant and } \\
\text { shop floor }\end{array}$ \\
\hline $\begin{array}{l}\text { Organisation } \\
\text { Work in groups, integration } \\
\text { of groups, complex tasks, } \\
\text { responsibility at execution } \\
\text { level, collaboration between } \\
\text { different departments }\end{array}$ & $\begin{array}{l}\text { Same } \\
\text { Volume of production close } \\
\text { to large batch production } \\
\text { production }\end{array}$ & $\begin{array}{l}\text { Small batch production in } \\
\text { small series close to } \\
\text { prototype production and } \\
\text { large series production }\end{array}$ \\
\hline $\begin{array}{l}\text { Industrial sectors } \\
\text { relations }\end{array}$ & $\begin{array}{l}\text { Mutomanical engineering and } \\
\text { related industries }\end{array}$ \\
\hline Source & Leadership & Participation \\
\hline
\end{tabular}

Source: Wobbe, 1992, 49.

The advantages of APS systems are evident though this model cannot be universally applied. Many factors must be taken into account, such as the type of production, firm size, type of organisation, power relationships, management practices with regard to human resources, existing skills and social competence, etc.

The APS model may be particularly appropriate when the level of product variety is high, and the level of quantity is low (prototype and small batch production), and/or when high standards of development and social needs are called for.

The diffusion of APS can lead to an increasing level of quality of working life of people who have jobs. But it is necessary to have awareness about the limited effect of APS in the quality of life in society as a whole. The APS promotion does not solve the unemployment and precarious 
job problems. The diffusion of APS can co-exist with the increase of unemployment and with the precarious jobs.

\section{CONCLUSIONS}

Diffusion of APS at European level requires changes in existing research programs. There should be a greater emphasis on the human and organisational factors rather than on technical considerations. Education and training programms should be reoriented towards human-centred strategy.

The human-centred orientation for industrial modernisation can also be adopted in a less industrialised country, like Portugal. The APS is not a new specific model for advanced European countries only. This orientation can be particularly recommended in sectors and firms with no Tayloristic traditions. Whilst, in a Taylorised sectors and firms many obstacles must be overcome.

Therefore is we feel it is imperative to prepare an industrial strategy within a development plan to serve as a point of reference for economic agents' decisions and specific policies (namely for scientific \& technologic, employment or vocational training policies) in orther to make these policies coherent. A strategy designed to raise the technological level of Portuguese industry must take into account the following:

a) modernisation of traditional industries, to ensure they remain competitive and become coherent on the strenght of quality requirements and flexible specialisation;

b) increase in technological level through more advanced technology transfers (and not just the more mature ones offering less risk factors), not forgetting the development of endogenous growth capability and the increase in the assimilation capability of more advanced technology, and specially of APS;

c) participation in co-operation at EU level (Information Technologies, EUREKA, Production Technologies, Telematics, etc.), in the development of new technical systems for the creation of new growth centres leading to reduced Portuguese dependency on equipment, foodstuff and energy sectors;

d) experimentations supported by Public Programmes to promote APS in mixed capital enterprises;

e) training programs for and dissemination of publications (books, booklets, videos, reports) among the social partners on APSt themes;

f) training programmes for all who are involved in the labour world, must include the human and social issues of production.

On the other hand, in view of the absence of a coherent financial policy supportive of research (which restricts the role of $R \& D$ government agencies), the more active groups in this area of flexible automated production. Should also to take part in European projects, where the Portuguese companies participation have been weak. It is therefore necessary to raise the level of R\&D to match APS technological requirements through local development efforts. If such efforts are not combined with some commercial strategy, there is a risk of poor results.

State administration must show determination in supporting laws designed to establish a basic framework of participation and co-operation between entrepreneurs and the work force, promote programs to facilitate technical refrecher and training, and also to relocate workers affected by technological advances. In the same way, experimental programmes should be introduced to innovate management techniques in mixed capital enterprises. Company managers and union leader feel it is indispensable to define a development plan at national level.

Finally, there is an urgent need to carry out empirical research on the socio-economic consequences of Tayloristic-technocentric systems (hidden costs of absenteeism, lack of quality, etc.), and to discover new organisational forms; specially those derived from or which facilitate implementation of anthropocentric automated production systems. Essentially, this 
implementation requires the knowledge of the socio-cultural reality of the industrial environment. The lack of innovative experimentations, also explains why new forms of work organisation are poorly known besides the fact that motivation and the human factor have not received the attention they deserve.

\section{REFERENCES}

Adler, P. S.: "Automation et qualification. Nouvelles orientation" (1987) Sociologie du Travail, $\mathrm{N}^{\circ} 3$

Altmann, N. e Düll, K. (1978) New Form of Work Organisation and Job Design in the Federal Republic of Germany: A Survey of Measures, Studies and Sociological Requirements, in: EFILWC: New Form of Work Organisation in the European Community Germany. Munich: European Foundation for the Improvement of Living and Working Conditions.

Brandt, D. (1992)Advanced Experiences with APS, 30 European Case Studies, FOP 246, Brussels, FAST/CEC.

Brödner, Peter (1990) Technocentric-anthropocentric Approaches: Towards skill-based Manufacturing, in: Warner, M.; Werner, W.; Brodner, P. (Ed.), New Technology and Manufacturing Management, John Wiley \& Sons .

FAST: Human Work in Avanced Technological Environment, CEC, June 1989

Gélinier, O. (1984) Stratégie de l'entreprise et motivation des hommes, Paris, Hommes et Téchniques.

Hertog, J.F.; Schroder, P. (1989) Social Research for Technological Change: Lessons from national programmes in Europe and North America, MERIT - Maastricht Economic Research Institute on Innovation and Technology, University of Limburg, Maastricht.

Jaikumar, R. (1986) Post-industrial manufacturing, Harvard Business Review, 6.

Jones, B.; Kovács, I.; Moniz, A.B. (1988), 'Understanding What Is the Human Factors in CIM Systems: Some International Evidence' in B.W. Rooks, CIM-Europe 1988 Conference: Present Achievements, Future Goals, Bedford, IFS Publication.

Kern, H.; Schumann, M. (1988) El Fin de la Division del Trabajo? Ministério de Trabajo y Seguridad Social, Madrid.

Kidd, P. (1992) Organisation, people and technology in European manufacturing, CEC, FAST, Brussels.

Kidd, P. (1988) Technology and engineering design: shaping a better future or repeating the mistakes of the past?, IEE PROCEEDINGS, Vol. 135, 5.

Kovács, Ilona et al. (1992) Sistemas flexiveis de produação e reorganização do trabalho, CESO I\&D, PEDIP, DGI.

Kovács, I. and Moniz, A.B. (1988) 'Aspects sociaux de l'automation industrielle au Portugal: Analyse de quelques cas' (Social Aspects of Industrial Automation in Portugal: Analysis of some Cases), in A.C. Gonçalves, A.T. Fernandes and C.L. d'Epinay (eds.), La Sociologie et les nouveaux défis de la modernisation, Oporto, AISLF/SSFLP.

Kovács, I.; Steiger-Garção, A. and Moniz, A.B. (1987) 'Flexible Production Systems and Work Organisation: The Portuguese Situation for the Nineties', Proc. 8th EGOS Colloquium Technology as the Two-Edged Sword of Organisational Change, Antwerpen, EGOS.

Kovács. I.; Moniz, A.B.; Mateus, A. (1991) Prospects for anthropocentric production systems in Portugal, CEC/FAST, Vol. 16, FOP 260, CEC.

Kovács. I.; Moniz, A.B. (1994) Trends for the development of anthropocentric production systems in small less industrialised countries: The case of Portugal, Proc. European Workshop in Human Centred Systems, Univ. Brighton-ERASMUS, Brighton.

Lehner, F. (1992) Anthropocentric production systems: the European response to advanced manufacturing and globalization, Brussels, CEC. 
Moniz, A.B. et al. (1989): Occupational Structure, Training and Labour Relations in the Metal Industries in Portugal, Lisbon, CESO I\&D/CEDEFOP.

Moniz, A.B.; Kovács. I.; Pereira, Z.L. (1994) "Quality and Work Organization with Advanced Automation in Portugal" in Kidd, P.; Karwowski, W.: Advances in Agile Manufacturing, Amsterdam, IOS Press, 675 - 679.

OCDE (1988) Nouvelle technologies, une estratégie socio-economique pour les années 90. OCDE, Paris.

Woomack, J. P. et al. (1990) The Machine that changed the world, Rawson Associates, New York.

\section{BIOGRAPHIES}

Ilona Kovács, is Full Professor of Sociology at the Faculty of Economics and Management of the Technical University of Lisbon, received her PhD in Economics Sociology at the University of Budapest, and is author of several books and articles on organisational innovation, vocational training for new competences and management strategies. She is also responsible of post-graduated course on Socio-organisational systems of the economical activities, and is consultant of industrial firms and social partners.

António Brandão Moniz, is Professor of Industrial Sociology at the Faculty of Sciences and Technology of University Nova of Lisbon, where received the $\mathrm{PhD}$ on Sociology of Industry and Work, and is author of books and articles on technological aspects, organisational design for FMS, and job design for automated systems. Is also researcher at UNINOVA Institute and consultant of industrial firms and social partners. 